\title{
Warm Perches: A Novel Approach For Reducing Cold Stress Effect on Production, Plasma Hormones, and Immunity in Laying Hens
}

Jiaying Hu

Purdue University

Heng Wei Cheng ( $\nabla$ Heng-Wei.Cheng@usda.gov )

USDAAgricultural Research Service

\section{Research}

Keywords: laying hen, cold stress, warm perch, performance, shell quality, thyroid hormone, cytokines

Posted Date: February 11th, 2021

DOl: https://doi.org/10.21203/rs.3.rs-181517/v1

License: (c) (1) This work is licensed under a Creative Commons Attribution 4.0 International License.

Read Full License 


\section{Warm perches: A novel approach for reducing cold stress effect on}

\section{production, plasma hormones, and immunity in laying hens}

Jiaying Hu, hu165@purdue.edu, Department of Animal Sciences, Purdue University, 750 S

Russel St., West Lafayette, IN 47907

Heng-wei Cheng*, heng-wei.cheng@usda.gov, Livestock Behavior Research Unit, USDA-

Agricultural Research Service, 750 S Russel St., West Lafayette, IN 47907

*: corresponding author 


\section{ABSTRACT:}

\section{Background:}

Cold temperature is a common environmental stressor that has a great impact on the poultry industries, inducing pathophysiological stress in birds with profound economic losses. Current methods used for preventing cold stress, such as reducing ventilation and using gas heaters, are facing challenges due to poor indoor air quality and its deleterious effects on bird and caretaker health. The aim of this study was to examine if the novelly designed warmed perch system, as a thermal device, can reduce cold stress-associated adverse effects on laying hens.

Methods:

Seventy-two 32-week-old DeKalb hens were randomly assigned to 36 cages arranged to 3 banks. The banks were assigned to 1 of 3 treatments: cages with warmed perches (WP; perches with circulating water at $30^{\circ} \mathrm{C}$ ), air perches (AP, regular perches only) or no perches (NP) for a 21 day trial. The room temperature was set at $10{ }^{\circ} \mathrm{C}$ during the entire experimental period. Rectal temperature and body weight were measured from the same bird of each cage at day $1,8,15$, and 21 during the cold exposure. Egg production was recorded daily. Feed intake, egg and eggshell quality were determined during the $1^{\text {st }}$ and $3^{\text {rd }}$ week of cold stress. Plasma levels of corticosterone, thyroid hormones (3, 3', 5-triiodothyronine and thyroxine), interleukin (IL)-6 and IL-10, were determined at day 1 and 21 post initiation of cold exposure. Results:

Compared to both AP and NP hens, WP hens were able to maintain their body temperature without increasing feed intake and losing body weight. The eggs laid by WP hens had thicker eggshell during the $3^{\text {rd }}$ week of cold exposure. Warmed perch hens also had a lower thyroxine conversion rate $(3,3$ ', 5-triiodothyronine/thyroxine) at day 1 , while higher plasma concentrations 
of IL-6 at day 21. Plasma levels of corticosterone, 3, 3', 5-triiodothyronine, and IL-10 were not different among treatments.

Conclusions:

Our results indicate that the warmed perch system can be used as a novel thermal device for preventing cold stress-induced negative effects on hen health and welfare through regulating innate immunity and metabolic hormonal homeostasis.

Key words: laying hen, cold stress, warm perch, performance, shell quality, thyroid hormone, cytokines 


\section{BACKGROUND}

The global climate change has caused frequent and intense heat waves, but also led to extreme low temperatures during winter months. Intense cold in animals increases feed intake, compromises their health and production, which further results in economic losses (Chen et al., 2012; van Iaer et al., 2014; Nguyen et al., 2016). Commercial laying hens have been genetically selected for high production with low body mass to increase feed conversion ratio. Egg production is energy demanding (Sakomura et al., 2019), together with the low body mass, commercial laying hens' performance could be worse in cold winter weather as compared to hot summer seasons. It has been estimated by environmental and heat-transference data that laying hens lost four times more energy during cold weather in order to maintain their body temperature (Alves et al., 2012). The deleterious effect of cold stress on hens can be even more severe toward the end-of-lay, when the hens have regularly lost a considerable amount of feather coverage (Beaulac et al., 2020).

Previous research conducted in poultry have revealed that acute cold stress suppresses the development, survivability, and production performance in birds (Sahin et al., 2003; Hulzebosch, 2006). For example, mortality due to immunosuppression and ascites is greatly increased in broiler chickens exposed to cold stress, due to cold ambient temperatures increase the oxygen requirement and cardiac output, together with peripheral vasoconstriction, leading to increased pulmonary arterial pressure (Ipeck and Sahan; 2006; Qureshi et al., 2018, Alba et al., 2019). In addition, to reduce increased costs associated with feed and heating budgets during winter, poultry producers often increase the barn temperature set point to reduce feed intake by birds, which in turn facilitates the ammonia $\left(\mathbf{N H}_{3}\right)$ emissions and dust built up inside the poultry houses. Ammonia level in laying house should be controlled under $10 \mathrm{ppm}$ without exceeded 25 
ppm (UEP, 2017), however, $\mathrm{NH}_{3}$ levels have been reported to be as high as from $40-100 \mathrm{ppm}$ (Ni et al., 2012) or 70-120 ppm (Liang et al., 2005), during winter seasons based on the type of houses. High $\mathrm{NH}_{3}$ concentrations adversely affect the health and production of hens as well as animal caretakers (Xin et al., 2011; Zhao et al., 2013), causing respiratory illness including coughing, upper respiratory tract bleeding, excessive secretions, and lung inflammation or infection (Kilic and Yaslioglu, 2014).

Chickens, like other homeothermic animals, maintain their core body temperature without extra effort within their thermoneutral zone, $16-23^{\circ} \mathrm{C}$. When the ambient temperature climbs above the upper or drop below the lower limit of the thermoneutral zone, heat exchange processes are induced between the body and the ambient environment (Van Kampen et al., 1979). During cold exposure, for example, the hypothalamus, as the thermoregulation center, initiates heat-retention responses, which includes cutaneous vasoconstriction and a variety of behavioral responses, reducing respiration rate and shivering to conserve or produce body heat (Boulant, 1981; Zhao et al., 2017). In addition, cold stress disrupts the biological homeostasis, impairing the hormonal and immune functions. In response to stress, the hypothalamic-pituitaryadrenal (HPA) axis increases release of corticosterone (CORT) from the adrenal glands, to promote gluconeogenesis in the tissues and lipolysis in the fat, by which CORT enhances glucose availability and energy metabolism (Schweiger et al., 2006; de Kloet and Herman, 2018). Increased plasma levels of CORT have been reported in young broilers chickens (Borsoi et al., 2015) and male turkeys (El-Halawani et al., 1973) under cold exposure. In addition, both 3, 3', 5-triiodothyronine (T3) and thyroxine (T4) are the most important thyroid hormones regulating energy metabolism for maintaining thermogenetic homeostasis (Klandorf et al., 1981; Decuypere et al., 2005). Exposing animals to low environmental temperature is associated with 
increased conversion of T4 to T3, which contributes to increased heat production (Galton and Nisula, 1969; Hangalapura et al., 2004). Furthermore, cold stress causes immunosuppression in animals by exacerbating pathophysiological conditions (Sinclair et al, 2013; Rastogi and Haldar, 2020). Interleukin 6, a pro-inflammatory factor and IL-10, an anti-inflammatory factor, have been used as indicators of innate immunity (Lin and Karin, 2007).

Egg laying strains of chickens are highly motivated to perch (Lambe and Scott, 1998; Olsson and Keeling, 2002); they exhibit signs of frustration and restless if perching opportunity is thwarted (Olsson and Keeling, 2000). Richly vascularized chicken feet and shanks are functionally as effective conductors to release/gain heat to/from the environment under hot/cold weather. During cold weather, the countercurrent heat exchange enables the blood to be warmed on its way returned to the heart through the superficial veins of the limbs (Dawson and Whittow, 2000). In chickens, more than $25 \%$ of metabolic heat can be transferred or regulated through their feet at the thermoneutral temperatures (Hillman and Scott, 1989). Based on the empirical heat transfer theory, laying hens may be beneficial during cold exposure by providing them with warmed perches for roosting. The objective of this study was to determine if the newly engineering designed warmed perch system, as a thermal device, can prevent the deleterious effects of cold stress in caged laying hens by assessing performance, egg quality, innate immunity cytokines, and the levels of CORT, and thyroid hormones.

\section{MATERIALS AND METHODS}

\section{Birds and Experimental Design}

The study was conducted in February 2019. All hens used in this experiment were housed and handled under the protocol approved by the Animal Care and Use Committee of Purdue University (PACUC\#: 1712001657). 
At 32 weeks of age, 72 DeKalb Laying hens were randomly housed in 2-birds cages (987 $\mathrm{cm}^{2} /$ hen; $\mathrm{n}=36$ ) arranged in 3 banks, and then assigned to 1 of 3 treatments: 1 ) warm perch (WP, perches with circulating warm water, $\left.30^{\circ} \mathrm{C}\right), 2$ ) air perch (AP, regular perches only), and 3) no perch (NP) inside a light-tight room for a 21-day (3 week) trail. Each cage provided: $12.6 \mathrm{~cm}$ feeder space/hen, as well as $38 \mathrm{~cm}$ perch space/hen in perch groups (WP and AP). A laying diet with $18.3 \% \mathrm{CP}, 2,890 \mathrm{kcal} \mathrm{ME} / \mathrm{kg}, 4.2 \% \mathrm{Ca}$, and $0.3 \%$ non-phytate phosphorus was fed to the chickens (DeKalb nutrition management guide, Version L7121-2, 2020). Hens had free access to food and water throughout the experiment. The lighting schedule was set at 16L: 8D.

\section{Warmed Perch System Design and Temperature Monitor}

A bank consisted of 3 rows with 4 cages per row. In the perch groups (WP and AP), 2 perches were connected to form a continuous loop per row. An electric water heater (Model: 6EP20-1, Richmond, Atlanta, GA) was used to supply warm water (temperature set point: $30^{\circ} \mathrm{C}$ ) for WP cages; and warm water was continuously circulating within each of loops via individual pumps during the three-week cold stress period. The AP cages had the same perch setting but without warm water circulating. The temperature and relative humidity $(\mathbf{T} / \mathbf{R H})$ data loggers (model ZW-007 for cages with perches and model ZW-003 for cages without perches, Onset Computer Co., Bourne, MA) were installed in each row. Two resistance temperature detectors (RTD) were installed in each of the warm perch loops to measure the supply and return water temperature (Figure 1a). Similarly, a single point for the air perch was also measured (Figure $1 b)$.

Room temperature was set at $10{ }^{\circ} \mathrm{C}$ with full ventilation. Both the room and cage temperature and room relative humidity were measured and recorded at 1-min intervals throughout the 
experimental period. Temperature and relative humidity data were averaged every $10 \mathrm{~min}$ for analysis.

\section{Physical and Physiological Sampling}

Body weight and rectal temperature were measured from the leg band tagged bird per cage at day 1 and then weekly during cold stress. Rectal temperature was determined using a digital thermometer (Model: TM99A, Cooper Atkins, Middlefield, CT).

The thermography of the feet was collected with an infrared camera (FLIR T440, FLIR systems, Inc.). The camera was set at an emissivity of 0.95 . Two images per bird were taken weekly (AP and WP birds' feet pictures were taken when they were roosting on the perches). The Images were analyzed using the FLIR Tools software (FLIR system Inc.); and the data were averaged for statistical analysis.

Feed intake of each cage was determined over 7 consecutive days during the $1^{\text {st }}$ and $3^{\text {rd }}$ week during cold stress. The amount of feed was weighed before adding to the trough, and the feed left in the trough and bucket was weighted at the end of each analysis week. The average daily feed intake per hen was calculated as: (Total $\mathrm{kg}$ feed in - $\mathrm{kg}$ feed left)/7 days/2 birds (Hu et al., 2019b).

A $5 \mathrm{ml}$ blood sample was taken from the untagged bird per cage ( $\mathrm{n}=12$ hens per treatment) via the brachial vein at both day 1 and day 21 during cold stress. To avoid any variation that might be caused by sampling time, one hen was sampled from each treatment consecutively until the end. The blood samples were centrifuged at $700 \mathrm{x}$ g for $20 \mathrm{~min}$ at $4^{\circ} \mathrm{C}$. The supernatant plasma was collected and stored at $-80^{\circ} \mathrm{C}$ until analysis.

\section{Egg Production and Quality}


Eggs production were recorded daily during the experimental period. Hen-day egg production was calculated as: the total number of eggs produced per cage/number of hens per cage $\mathrm{x} 100$. Four intact hard-shelled eggs were randomly collected from each cage (48 eggs/treatment) during 3 consecutive days (Monday to Wednesday) at the $1^{\text {st }}$ and $3^{\text {rd }}$ week, respectively. Each collected egg was weighed and measured for breaking force individually. The eggs were then

frozen to crack the shells. The yolk and albumen were removed from each egg after thawing and discarded. The shell with intact shell membranes was rinsed with water and dried at $60{ }^{\circ} \mathrm{C}$. The dried shell weight was recorded. Shell thickness and $\%$ shell mass were determined as described by Hu et al. (2019b).

\section{Plasma Corticosterone}

Plasma CORT concentrations were measured using a commercially available radioimmunoassay kit (Catalog \#: 07120103, MP Biomedicals, Solon, OH). Total plasma CORT concentrations were analyzed in duplicate following the protocol described by Cheng et al. (2001).

\section{Plasma Thyroid Hormones}

Plasma concentrations of T3 (Catalog \#: 06B-254216, MP Biomedicals, Solon, OH) and T4 (Catalog \#: 06B-254030, MP Biomedicals, Solon, OH) were analyzed with the commercially available ${ }^{\mathrm{I} 25}$ RIA kits by following the company's protocols. Briefly, the mixture of $100 \mu$ of T3 standard or plasma sample with $\mathrm{T} 3$ tracer was incubated in a water bath at $37^{\circ} \mathrm{C}$ for $60 \mathrm{~min}$. At the end of the incubation, all tubes were vacated, and the radioactivity was counted at 1 min per sample with a gamma counter (1470 Wizard Gamma Counter, PerkinElmer, Waltham, MA). A similar procedure was used for $\mathrm{T} 4$ analysis except that the counting time was $30 \mathrm{sec}$ per sample. 
T3/T4 ratio was calculated for each sample. All samples were measured in duplicate with $\mathrm{CV} \leq$ 15\% (Hu et al., 2019a; Yan et al., 2020).

\section{Plasma cytokines Interleukin-6, and Interleukin-10}

Plasma concentrations of IL-6 and IL-10 (Catalog \#: MBS037319, MBS007312,

MyBiosource, San Diego, CA) at day 1 and day 21 post cold stress initiation were analyzed with the commercially available ELISA kits by following the company's protocols. All samples were measured in duplicate with $\mathrm{CV} \leq 15 \%$ (Hu et al., 2019a; Yan et al., 2020).

\section{Statistical Analysis}

Data from the randomized design were subjected to an ANOVA using the MIXED method of SAS 9.4 software (SAS Institute Inc., Cary, NC). Repeated measures were used for performance and physiological traits with row of cages within treatment serving as the experimental unit. Each of the 4 cages within a row of a treatment served as a subsample. Fixed effects were treatment and age of the hens. Subsampling error terms included cages within row and hens within cages within row. Pooling of error terms occurred when $P>0.25$. If data lacked homogenous variances, transformations of arcsine square root were used for egg production data, and BOX-COX was used for other data, and the data reanalyzed. Because statistical trends were similar for both transformed and untransformed data, the untransformed results are presented. Tukey-Kramer was used to partition differences among means due to significant treatment effects (Steel et al., 1997). The SLICE option was used for the 2-way interaction of treatment and age (Winer et al., 1991). Significant statistical differences were reported when $P \leqslant 0.05$, a trend was reported when $0.05<P \leqslant 0.1$. 


\section{RESULTS}

Average daily room ambient temperature was at $11.24^{\circ} \mathrm{C}\left(6.65-17.25^{\circ} \mathrm{C}\right)$, and room relative humidity was at average of $49 \%$ (30 - 67\%) throughout the entire experimental period. A typical day room temperature and perch temperatures are shown in Figure 2a. The WP successfully provided a warm source for the hens as indicated by the much higher perch temperature compared to the cage, room, and AP temperature (Figure 2a). The feet temperature of a hen standing on the WP were greatly higher (Figure $2 b$ ) than those of a hen roosting on the AP (Figure 2c).

Rectal temperature was higher in both WP and AP hens than NP hens $\left(P_{\text {treatment }}<0.0001\right.$, Table 1). Foot surface temperature was warmer in WP hens than NP hens, and AP hens were intermediate $\left(P_{\text {treatment }}<0.0001\right.$, Table 1$)$. WP hens tended to have lower feed intake than NP but not AP hens $\left(P_{\text {treatment }}=0.06\right.$, Table 1$)$. The BW loss had a trend to be lower in WP hens than AP hens but not NP hens $\left(P_{\text {treatment }}=0.09\right.$, Table 1$)$. Egg production was not affected by the treatments $(\mathrm{P}>0.05)$ but was reduced as cold stress persist $\left(P_{\text {age }}=0.04\right.$, Table 2$)$. There was no treatment effect on egg weight, egg breaking force, shell thickness, and shell percentage $(P>$ 0.05; Table 2) except that the eggs from WP group during the $3^{\text {rd }}$ week of cold exposure had

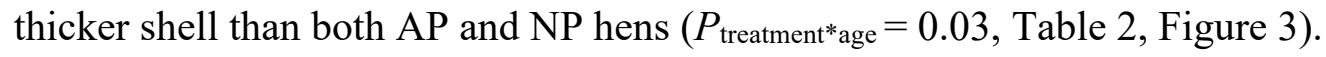

Plasma concentrations of CORT, T3, and IL-10 were not different among treatments; while T4 levels were higher in both WP and NP hens than AP hens $\left(P_{\text {treatment }}=0.002\right.$, Table 3$)$. T3/T4

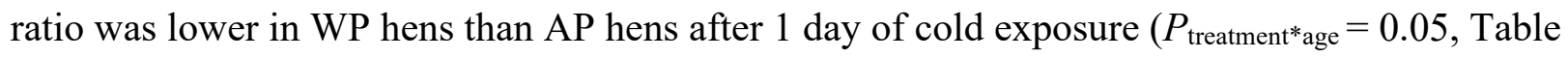
3, Figure 4a), while NP hens were intermediate. Plasma IL-6 level was higher in WP than NP hens but not AP hens at 21 day of cold exposure $\left(P_{\text {treatment } *^{*} \text { ge }}=0.04\right.$, Table 3, Figure $\left.4 \mathrm{~b}\right)$. 


\section{DISCUSSIONS}

The results from the current study indicated that provision of WP for laying hens has beneficial effect on maintaining body temperature and feed intake without compromising body weight, egg production and egg quality under cold conditions. Generally, when animals are exposed to cold environment, the activated hypothalamic thermoregulatory center increases thermogenesis via vasoconstriction and various endocrine mechanisms for conserving heat loss to maintain core body temperature (Robertshaw, 2006; Collier et al., 2019; Habibu et al., 2019). Additionally, the countercurrent heat exchange and arteriovenous anastomoses (AVAs) systems enable avian species to have their feet in contacting with cold surface at high endogenous heat production and energy costs (Hillman et al., 1982; Midtgard, 1989). In the current study, compared to NP hens, both WP and AP hens were able to maintain their core temperature, but the underlaying mechanisms could be different. In WP hens, when they are contacting with a heat source (i.e, the perches with circulating water at $30^{\circ} \mathrm{C}$ ), they are able to receive extra heat from the warmed perches, which is beneficial for them to maintain core body temperature; and this is evidenced by the warmest foot surface temperature determined in the WP hens among the three groups. In AP group, the higher core body temperature observed could be due to adjusted metabolic heat production during digestion (Chepete and Xin, 2004; Lu et al., 2017) and fatburning during lipolysis and perching movement (Gebhardt-Henrich et al., 2017), which is supported by approximately $10 \%$ of their body weight loss after 3 weeks of cold exposure.

Birds derive the majority of their energy from the food intake. In order to cope with the heat loss under cold weather, birds spontaneously consume excessive feed to maintain energy required (Ferket and Gernat, 2006) at an estimated of $1.5 \mathrm{~g} / 1^{\circ} \mathrm{C}$ per hen (Hulzebosch, 2006). An early study conducted by El-Wailly (1966) indicated that the gross feed intake in zebra finch was 
linearly increased with decreasing environmental temperature. Similarly, low ambient temperatures in laying hens cause an increase in feed intake, but decrease of egg production, egg quality and feed efficiency (Spinu and Degen, 1993; Kucuk et al., 2006). With the negative effect of cold stress, farmers may suffer from increased feed costs and reduced egg production during winter seasons, which leads to considerable economic losses. In order to keep hen warm while balancing out the heating and feed costs, farmers usually restrict the ventilation to maintain the ambient temperature. Chickens and related waste generated inside the barns lead to air pollutions, including $\mathrm{NH}_{3}$, carbon dioxide, methane, hydrogen sulfide, nitrous oxide gases, and dust (Kocaman et al., 2005; Green et al., 2009). Poor ventilation causes accumulation of these gases to a possible toxic level. Inhalation of gaseous $\mathrm{NH}_{3}$ or $\mathrm{NH}_{3}$ bound to dust particles can damage the mucous flow and ciliary action in the trachea (Anderson et al., 1968; Nagaraja et al., 1984; David et al., 2015), leading to great susceptibility of diseases in chickens (Al Homidan et al., 1998; Kristensen et al., 2000; Banhazi et al., 2008) as well as respiratory irritation in poultry workers and chicken catchers (Sanderson et al. 1995; Rees et al. 1998). In the current study, under the condition of full ventilation and low ambient temperature $\left(10^{\circ} \mathrm{C}\right)$, as compared with other two groups of hens, provision of WP tended to prevent the increase of feed consumption but still able to maintain body weight and egg production rate, by which it may provide benefits without compromising air quality in the poultry house although the further studies are needed.

Egg production and quality are closely related to calcium $(\mathbf{C a})$ availability. Animals stressed due to environmental temperature are found to impair gastrointestinal (GI) function and increase GI permeability (Karl et al., 2018). Environmental factors affecting gut microbiota populations have been investigated in humans and animals (Cholewinska et al., 2021; Moeller et al., 2020; Vandenplas et al., 2020). Moreover, cold stress induced vasoconstriction, which results in an 
increase in efferent sympathetic activity and a reduction in parasympathetic activity (ManouStathopoulou et al., 2015, Greaney et al., 2015, 2017). In chickens, specifically, high blood pressure due to vasoconstriction can lead to ascites in broilers; while in laying hens, it reduces adequate blood flow to the gut and uterus, could reduce nutrients absorption and eggshell calcium deposition (Nolan et al., 1978). Eggs collected from WP hens were not differ during the $1^{\text {st }}$ week of cold exposure, but had thicker eggshell than both AP and NP hens during the $3^{\text {rd }}$ week, indicating installation of WP facilitates the hens to better cope with the low ambient temperature and utilize the Ca during eggshell formation.

Plasma levels of CORT have been used as a marker for evaluating acute physiological coping ability (Kunz-Ebrecht et al., 2003). Stress activates the HPA axis to release glucocorticoids from the adrenal glands. With cold exposure, acute surge of glucocorticoids enhances lipolysis and attenuates glucose uptake within the adipose tissue in order to cope with the demand for supplying metabolic energy to the brain and other crucial organs (Schweiger et al., 2006; Campbell et al., 2009; Ramage et al., 2016). Unlike short-term glucocorticoids increases, prolonged elevation of endogenous glucocorticoids has been found to be highly involved in energy homeostasis and adipose tissue metabolism (Luijten et al., 2019). Overexpression of glucocorticoids has been proved to lead to accumulation of brown adipose tissue (BAT) and increase in lipogenesis of white adipose tissue (WAT), resulting in metabolic disorders in both mice and humans (John et al., 2016; Pasieka and Rafacho, 2016; Infante et al., 2017). In poultry, controversial results have been reported regarding to plasma CORT in response to cold stress. With various durations of cold exposure and stress levels, an increase of CORT was found in broiler chickens $\left(12^{\circ} \mathrm{C}\right.$ for $24 \mathrm{~d}$; Olfati et al., 2018), chicks $\left(1.2^{\circ} \mathrm{C}\right.$ for $3 \mathrm{hr}$; Buckland et al., 1974), and laying hens $\left({ }^{\circ} \mathrm{C}\right.$ for $72 \mathrm{hr}$; Hester et al., 1996). In contrast, Hangalapura et al. (2004) 
reported a suppressive effect of cold stress on CORT. In the current study, the CORT level was not affected by the treatments. The unchanged CORT could probably due to the negative feedback of CORT on the HPA axis with continuously cold exposure, resulting in an inhibition of adrenocorticotropin secretion (Vandernborne et al., 2005). Similarly, previous studies have reported that constantly elevated CORT is not commonly seen under chronic or repeated stress possibly due to the negative feedback of CORT on the HPA axis (Romero, 2002, 2004; Smith and Vale, 2006; Angelier and Wingfield, 2013). The hypothesis will be tested in our future studies.

Thyroid hormones, including both T3 and T4, play important roles in energy metabolism and thermogenesis (Wrutniak-Cabello et al., 2001; McNabb, 2006). Cold exposure has been shown to enhance the conversion from T4 to T3 in order to increase heat production in birds (Burger and Denver, 2002; Collin et al., 2003; Zheng et al., 2013), rodents (Park et al., 2017), and humans (Levine et al., 1995; Bojko, 1997). Birds acclimated to cold temperature have increased thyroid gland size and functional activities than control ones (Faure et al., 2013; McNabb, 2014). In the current experiment, T4 was found higher in both WP and NP groups than AP group. The provision of WP could possibly allow the chickens to gain heat from the WP, which in turn reduces the need of endogenous heat production from conversion of $\mathrm{T} 4$ to $\mathrm{T} 3$, thus leads to higher peripheral T4 determined in WP chickens. In agreement with our results, chronic cold stress have been reported to reduce T4 synthesis and release in a variety of animals (Buffenstein et al., 2001; Mustafa and Elgazzar, 2014; Zhang et al., 2018). With respect to acute cold stress, Rudas and Pethes (1986) indicated that the increased conversion of T4 to T3 is an acute cold adaptation in birds, resulting in an acute drop in peripheral T4 and increase in T3/T4 ratio. Similarly, after $1 \mathrm{~d}$ of cold exposure (an acute cold stress), we found a lower T3/T4 ratio in WP 
hens, suggesting the WP installation could possibly reduce the stress intensity and facilitate the chickens with better adaptation to acute cold stimulations. Furthermore, Silberman et al. (2002) described a suppressed thyroid function in response to chronic stress in mice. Therefore, the higher T4 found in WP hens could also be considered as an indicator for ameliorated stress response with provision of WP. While the higher T4 levels found in the NP hens were probably resulted from the increased metabolic and digestive heat from excessive feed intake (141.7 $\mathrm{g}>$ $133.9 \mathrm{~g}>121.3 \mathrm{~g} ; \mathrm{NP}>\mathrm{AP}>\mathrm{WP})$.

Prolonged environment stressor exposure can weaken the immune system, leading to immunosuppression. In rodent studies, both acute and chronic cold stress contribute to the immune-suppressive state in the animals (Kizaki et al., 1996; Rykakina et al., 1997; Sesti-Costa et al., 2012). In chickens, studies have reported cold stress decrease the number of lymphocytes, which leads to increased heterophil to lymphocyte ratio which has been used as a stress indicator in various animals including chickens (Hester et al., 1996; Campo et al., 2008; Olfati et al., 2018). In both humans and animals, IL-6 promotes the migration and proliferation of both T and B lymphocytes (Lippitz, 2013). Interleukin-10, as an anti-inflammatory cytokine, has a protective property in inflammation and infection by limiting the immune response to pathogens. Our data shown the peripheral IL-6 level was higher in WP group than NP hens exposed to cold ambient temperature for 3 weeks, which could possibly indicate that the prolonged cold stress has contributed to the immunosuppression in NP hens, while the provision of warmed perches could ameliorate the negative effect of low ambient temperature. No difference in IL-10 concentration among the three treatments was observed in the current experiment. In contrast to the possible immunosuppressive state found under the current cold stress condition, Hangalapura et al. (2006) reported that cold stress stimulates immune response, resulting in increased IL-6 but 
reduced IL-10 concentrations in chickens exposed to cold stress at $10{ }^{\circ} \mathrm{C}$ for 43 days. In that study, the birds used in that experiment were 23 day-old when the cold stress was initiated. As one of the reasons of the different findings, the immune response to cold stress could be affected differently in chickens as well as in other animals at different ages (Gaunson et al., 2006; Ge et al., 2020).

In conclusion, provision of WP assisted DeKalb laying hens with thermoregulation during the cold exposure as indicated in the measured outcomes including feed consumption, body weight, rectal temperature, foot surface temperature, egg quality traits, thyroid hormones and immunoregulation. The results show that the warmed perch system could be a novel thermal device for reducing cold stress during winter seasons. It also provides new sights for examining the effects of the WP system on different growth phases of laying hens under various cold conditions. 


\section{LIST OF ABBREVIATIONS}

WP: cages with warm perches

AP: cages with air perches

NP: cages without perches

CORT: corticosterone

IL: interleukin

$\mathrm{NH}_{3}$ : ammonia

HPA: hypothalamic-pituitary-adrenal axis

T3: 3, 3', 5-triiodothyronine

T4: thyroxine

T/RH: temperature and relative humidity

RTD: resistance temperature detectors

AVAs: arteriovenous anastomoses systems

Ca: calcium

GI: gastrointestinal

BAT: brown adipose tissue

WAT: white adipose tissue 


\section{DECLARATIONS}

Ethics approval and consent to participate

- All hens used in this experiment were housed and cared for under the protocol approved by the Animal Care and Use Committee of Purdue University (PACUC\#: 1712001657).

Consent for publication

- Not applicable

Availability of data and materials

- The datasets used and/or analyzed during the current study are available from the corresponding author on reasonable request.

- All data generated and/or analyzed during this study are included in this published article.

Competing interests

- The authors have declared that no competing interests exist.

Authors' contributions

- $\mathrm{JH}$ and $\mathrm{HC}$ designed the study. JH analyzed and interpreted all data included in this article and was a major contributor in writing the manuscript. Both authors read and approved the final manuscript.

\section{Acknowledgements}

- We would like to thank the staff and graduate students of the Livestock Behavior Research Unit, USDA-ARS and the Department of Animal Sciences of Purdue University for their assistance in conducting this study. Mention of trade names or commercial products in this article is solely for the purpose of providing specific 
information and does not imply recommendation or endorsement of the USDA. The USDA is an equal opportunity provider and employer. 


\section{REFERENCES}

Al Homidan A, Robertson JF, Petchey AM. Review of the effect of ammonia and dust concentrations on broiler performance. World's Poult Sci J. 2003; 59:340-349.

Alba BK, Castellani JW, Charkoudian N. Cold-induced cutaneous vasoconstriction in humans: function, dysfunction and the distinctly counterproductive. Exp Physio. 2019; 104: 12021214.

Alves FMS, Felix GA, Almeida Paz ICL, Naaas IS, Souza GM, Caldara FR, Garcia RG. Impact of exposure to cold on layer production. Rev. Bras. Cienc. Avic. 2012; 14: 3.

Anderson DP, Beard CW, Hanson RP. The adverse effects of ammonia on chickens including resistance to infection with Newcastle disease virus. Avian Res. 1964; 8:369-379.

Angelier F, Wingfield JC. Importance of the glucocorticoid stress response in a changing world: Theory, hypotheses and perspectives. Gen Comp Endocrinol. 2013; 190:118-128.

Banhazi TM, Seedorf J, Laffrique M, Rutley DL. Identification of the risk factors for high airborne particle concentrations in broiler buildings using statistical modelling. Biosystems Eng. 2008; 101:100-110.

Beaulac K, Crowe TG, Schwean-Lardner K. Stimulated transport of well- and poor- feathered brown-strain end-of-cycle hens and the impact on stress physiology, behavior, and meat quality. Poult Sci. 2020; 99: 6753-6763.

Bojko ER. Metabolical changes induced by adaptation to circumpolar conditions in Spitsbergen. Int J Circumpolar Health. 1997; 56:134.

Borsoi A, Quinteiro-Filho WM, Calefi AS, Ferreira AJP, Astolfi-Ferreira CS, Florio JC, Palermo-Neto J. Effects of cold stress and Salmonella Heidelberg infection on bacterial load and immunity of chickens. Avian Pathol. 2015; 44:490-497. 
Boulant, J. A. 1981. Hypothalamic mechanisms in thermoregulation. Fed. Proc. 40: 2843-2850.

Buckland RB, Blagrave K, Lagnë PC. Competitive protein-binding assay for corticoids in the peripheral plasma of the immature chicken. Poult Sci. 1974; 53:241-245.

Buffenstein R, Woodley R, Thomadakis C, Daly TJM, Gray DA. Cold-induced changes in thyroid function in a poikilothermic mammal, the naked mole-rat. Am J Physiol Regulatory Integrative Comp Physiol. 2001; 280: R149-R155.

Burger MF, Denver RJ. Plasma thyroid hormone concentrations in a wintering passerine bird: Their relationship to geographic variation, environmental factors, metabolic rate, and body fat. Phyiol Biochem Zool. 2002; 75:187-199.

Campbell JE, Fediuc S, Hawke TJ, Riddell MC. Endurance exercise training increases adipose tissue glucocorticoid exposure: adaptations that facilitate lipolysis. Metabolism. 2009; 58:651660.

Campo JL, Prieto MT, Davila SG. Effects of housing system and cold stress on heterophil-tolymphocyte ratio, fluctuating asymmetry, and tonic immobility duration of chickens. Poult Sci. 2008; 87: 621-626.

Chen R, Jiang R, Geng Z. Cold stress in broiler: global gene expression analyses suggest a major role of CYP genes in cold responses. Mol Biol Rep. 2012; 39:425-429.

Cheng HW, Dillworth G, Singleton P, Chen Y, Muir WM. Effects of group selection for productivity and longevity on blood concentrations of serotonin, catecholamines, and corticosterone of laying hens. Poult Sci. 2001; 80: 1278-1285.

Chepete $\mathrm{JH}, \mathrm{Xin} \mathrm{H}$. Heat and moisture production of poultry and their housing system: molting hens. Trans ASHRAE. 2004; 110:274-285.

Cholewińska P, Górniak W, Wojnarowski K. Impact of selected environmental factors on 
microbiome of the digestive tract of ruminants. BMC Vet Res. 2021; 17:25.

Collier RJ, Baumgard LH, Zimbelman RB, Xiao Y. Heat stress: physiology of acclimation and adaption. Anim Front. 2019; 9:12-19.

Collin A, Buyse J, van As P, Darras VM, Malheiros RD, Moraes VMB, Reyns GE, Taouis M, Decuypere E. Cold-induced enhancement of avian uncoupling protein expression, heat production, and triiodothyronine concentrations in broiler chicks. Gen Comp Endocrinol. $2003 ; 130: 70-77$.

David B, Mejdell C, Michel V, Lund V, Moe RO. Air quality in alternative housing systems may have an impact on laying hen welfare. Part II-Ammonia. Animals. 2015; 5:886-896.

Dawson WR, Whittow GC. Regulation of body temperature. In Whittow GC, editor. Sturkie's Avian Physiology. New York, NY: Academic press; 2000. p. 343-390.

de Kloet AD, Herman JP. Fat-brain connections: adipocyte glucocorticoid control of stress and metabolism. Front Neuroendocrinol. 2018; 48:50-57.

Decuypere E, Van As P, Van der Geyten S, Darras VM. Thyroid hormone availability and activity in avian species: A review. Domest Anim Endocrinol. 2005; 29:63-77.

DeKalb nutrition management guide. 2020. Available at https://layinghens.hendrixgenetics.com/documents/883/Nutrition_Guide.pdf. Accessed Dec. 2020.

El-Halawani ME, Waibel PE, Appel JR, Good AL. Effects of temperature stress on catecholamines and corticosterone of male turkeys. Am J Physiol. 1973; 224:384-388.

El-Wailly AJ. Energy requirements for egg-laying and incubation in the zebra finch, Taeniopygia castanotis. Condor. 1966; 68:582.

Faure J, Lebret B, Bonhomme N, Ecolan P, Kouba M, Lefaucheur L. Metabolic adaptation of two pig muscles to cold rearing conditions. J Anim Sci. 2013; 91:1893-1906. 
Ferket PR, Gernat AG. Factors that affect feed intake of meat birds: A review. Int J Poult Sci. 2006; 5:905-911.

Galton A, Nisula BC. Thyroxine metabolism and thyroid function in the cold-adapted rat. Endocrinology. 1969; 85:79-86.

Gaunson JE, Philip CJ, Whithear KG, Browning GF. Age related differences in the immune response to vaccination and infection with Mycoplasma gallisepticum. Vaccine. 2006; 24: $1687-1692$.

Ge N, Westbrook R, Langdon J, Yang H, Marx R, Abadir P, Xue QL, Walston JD. Plasma levels of corticosterone, tumor necrosis factor receptor 1 and interleukin 6 are influenced by age, sex and chronic inflammation in mice treated with acute temperature stress. Exp Gerontol. 2020; 42:111136.

Gebhardt-Henrich SG, Toscano MJ, Würbel H. Perch use by broiler breeders and its implication on health and production. Poult Sci. 2017; 96:3539-3549.

Greaney JL, Alexander LM, Kenney WL. Sympathetic control of reflex cutaneous vasoconstriction in human aging. J Appl Physiol. 2015; 119:771-782.

Greaney JL, Kenney WL, Alexander LM. Neurovascular mechanisms underlying augmented cold induced reflex cutaneous vasoconstriction in human hypertension. J Physiol. 2017; 595:1687-1698.

Green AR, Wesley I, Trampel DW, Xin H. Air quality and bird health status in three types of commercial egg layer houses. J Appl Poultry Res. 2009; 18:605-621.

Habibu B, Yaqub LS, Dzenda T, Kawu MU. Sensitivity, impact and consequences of changes in respiratory rate during thermoregulation in livestock - A review. Ann Anim Sci. 2019; 19:291-304. 
Hangalapura BM, Kaiser MG, van der Poel JJ, Parmentier HK, Lamont SJ. Cold stress equally enhances in vivo proinflammatory cytokine gene expression in chicken lines divergently selected for antibody responses. Dev Comp Immunol. 2006; 30: 503-511.

Hangalapura BN, Nieuwland MGB, Kemp B, Parmentier HK. Effect of duration of cold stress on plasma adrenal and thyroid hormone levels and immune responses in chicken lines divergently selected for antibody responses. Poult Sci. 2004; 83:1644-1649.

Hester PY, Muir WM, Craig JV, Albright JL. Group selection for adaptation to multi-hen cages: Hematology and adrenal function. Poult Sci. 1996; 75:1295-1307.

Hillman PE, Scott NR. Energy budget of the chicken foot. J Therm Biol. 1989; 14:205-217. Hillman PT, Scott NR, van Tienhoven A. Vasomotion in chicken foot: dual innervation of arteriovenous anastomoses. Am J Physiol. 1982; 242: R582-R590.

Hu JY, Hester PY, Makagon MM, Xiong Y, Gates RS, Cheng HW. Effect of cooled perches on performance, plumage condition, and foot health of caged White Leghorn hens exposed to cyclic heat. Poult Sci. 2019a; 98:2705-2718.

Hu JY, Hester PY, Makagon MM, Xiong Y, Gates RS, Cheng HW. Effect of cooled perches on physiological parameters of caged White Leghorn hens exposed to cyclic heat. Poult Sci. 2019b; 98:2317-2325.

Huizebosch, J. Effective heating systems for poultry houses. World Poult. 2006; 22: 2. Infante M, Armani A, Mammi C, Fabbri A, Caprio M. Impact of adrenal steroids on regulation of adipose tissue. Adipose Tissue Compr Physiol. 2017; 12:1425-1447.

Ipeck A, Sahan U. 2006. Effects of cold stress on broiler performance and ascites susceptibility. Asian Austral J Anim. 2006; 19:734-738.

John K, Marino JS, Sanchez ER, Hinds TD Jr. The glucocorticoid receptor: cause of or cure for 
obesity? Am J Physiol Endocrinol Metab. 2016; 310: E249-E257.

Karl JP, Hatch AM, Arcidiacono SM, Pearce SC, Pantoja-Feliciano IG, Doherty LA, Soares JW. Effects of psychological, environmental and physical stressors on the gut microbiota. Front Microbiol. 2018; 11.

Kilic I, Yaslioglu E. Ammonia and carbon dioxide concentrations in a layer house. Asian Austral J Anim. 2014; 27:1211-1218.

Kirschbaum C, Pirke KM, Hellhammer DH. The 'Trier Social Stress Test'--a tool for investigating psychobiological stress responses in a laboratory setting. Neuropsychobiology. $1993 ; 28: 76-81$.

Kizaki T, Oh-ishi S, Ohno H. Acute cold stress induces suppressor macrophages in mice. J Appl Physio. 1996; 81: 393-399.

Klandorf H, Sharp PJ, Macleod MG. The relationship between heat production and concentrations of plasma thyroid hormones in the domestic hen. Gen Comp Endocrinol. 1981; 45:513-520.

Kocaman B, Esenbuga N, Yildiz A, Macit M. Effect of environmental conditions in poultry houses on the performance of laying hens. Int J Poul. Sci. 2006; 5: 26-30.

Kristensen H, Burgess LR, Demmers TGH, Wathes CW. The preferences of laying hens for different concentrations of atmospheric ammonia. Appl Anim Behav Sci. 2000; 68:307-318.

Kucuk O, Sahin N, Sahin K, Gursu MF, Gulcu F, Ozcelik M, Issi M. Egg production, egg quality, and lipid peroxidation status in laying hens maintained at a low ambient temperature $\left(6^{\circ} \mathrm{C}\right)$ and fed a vitamin $\mathrm{C}$ and vitamin E-supplemented diet. Vet Med-Czech. 2006; 48:33-40. Kunz-Ebrecht S, Mohamed-Ali V, Feldman PJ, Kirschbaum C, Steptoe A. Cortisol responses to mild psychological stress are inversely associated with proinflammatory cytokines. Brain 
Behav Immun. 2003; 17: 373-383.

Lambe NR, Scott GB. Perching behavior and preferences for different perch designs among laying hens. Anim Welf. 1998; 7:203-216.

Levine M, Duffy L, Moore DC, Matej LA. Acclimation of a non-indigenous sub-Arctic population: seasonal variation in thyroid function in interior Alaska. Comp Biochem Physiol B. $1995 ; 111: 209-214$.

Liang Y, Xin H, Wheeler EF, Gates RS, Li H, Zajaczkowski JS, Topper PA, Casey KD, Behrends BR, Burnham DJ, Zajaczkowski FJ. Ammonia emissions from U. S. Laying hen houses in Iowa and Pennysylvania. Tran of ASAE. 2005; 48: 1927-1941.

Lin WW, Karin M. A cytokine-mediated link between innate immunity, inflammation, and cancer. J Clin Invest. 2007; 117: 1175-1183.

Lippitz BE. Cytokine patterns in patients with cancer: a systematic review. Lancet Oncol. 2013; 14: e218-e228.

Lu XY, Solmonson A, Lodi A, Nowinski SM, Sentandreu E, Riley CL, Mills EM, Tiziani S. 2017. The early metabolomic response of adipose tissue during acute cold exposure in mice. Sci Rep. 2017; 7:3455.

Luijten IHN, Cannon B, Nedergaard J. Glucocorticoids and brown adipose tissue: do glucocorticoids really inhibit thermogenesis? Mol Aspects Med. 2019; 68:42-59.

Manou-Stathopoulou V, Goodwin CD, Patterson T, Redwood SR, Marber MS, Williams RP. The effects of cold and exercise on the cardiovascular system. Heart. 2015; 101: 739-741. McNabb FMA, Darras VM. Thyroids. In: Scanes E, editor. Sturkie's Avian Physiology. New York, NY: Academic press; 2014. p. 535-544.

McNabb FMA. Avian thyroid development and adaptive plasticity. Gen Comp Endocrinol. 2006; 
147:93-101.

Midtgard U. Development of arteriovenous anastomoses in the skin of the chicken and the influence of environmental temperature. Am J Anat. 1989; 186:300-305.

Moeller AH, Sanders JG. Roles of the gut microbiota in the adaptive evolution of mammalian species. Philos Trans R Soc Lond B Biol Sci. 2020; 375:20190597.

Mustafa S, Elgazzar A. Influence of chronic exposure to cold environment on thyroid gland function in rabbits. Horm Metab Res. 2014; 46:546-549.

Nagaraja KV, Emery DA, Jordan KA, Sivanandan V, Newman JA, Pomeroy BS. Effect of ammonia on the quantitative clearance of escherichia coli from lungs, air sacs, and livers of turkeys aerosol vaccinated against Escherichia coli. Am J Vet Res. 1984; 45:392-395.

Nguyen PH, Greene E, Donoghue A, Huff G, Clark F, Dribi S. A new insight into cold stress in poultry production. Adv Food Technol Nutr Sci. 2016; 2:1-2.

Ni JQ, Chai L, Chen L, Bogan BW, Wang K, Cortus EL, Heber AJ, Lim TT, Diehl CA. Characteristics of ammonia, hydrogen sulfide, carbon dioxide, and particulate matter concentrations in high-rise and manure-belt layer hen houses. Atmos. Environ. 2012; 57: $165-174$.

Nolan WF, Weathers WW, Sturkie PD. Thermally induced peripheral blood flow changes in chickens. J Appl Physiol. 1978; 44:81-84.

Olfati A, Mojtahedin A, Sadeghi T, Akbari M, Martines-Pastor F. Comparison of growth performance and immune responses of broiler chicks reared under heat stress, cold stress and thermoneutral conditions. Span J Agric Rec. 2018; 16:e0505.

Olsson IAS, Keeling LJ. Night-time roosting in laying hens and the effect of thwarting access to perches. Appl Anim Behav Sci. 2000; 68:243-256. 
Olsson IAS, Keeling LJ. The push-door for measuring motivation in hens: Laying hens are motivated to perch at night. Anim Welf. 2002; 11:11-19.

Park GC, Kim JM, Park HY, Han JM, Shin SC, Jang JY, Jung D, Kim IJ, Lee JC, Lee BJ. TSHindependent release of thyroid hormones through cold exposure in aging rates. Oncotarget. 2017; 8:89431-89438.

Pasieka MP, Rafacho A. Impact of glucocorticoid excess on glucose tolerance: clinical and preclinical evidence. Metabolites. 2016; 6:24.

Qureshi S, Khan HM, Mir MS, Raja T, Khan A, Ali H, Adli S. Effect of cold stress and various suitable remedies on performance of broiler chicken. J Worlds Poult Res. 2018; 8: 66-73.

Ramage LE, Akyol M, Fletcher AM, Forsythe J, Nixon M, Carter RN, van Beek EJR, Morton NM, Walker BR, Stimson RH. Glucocorticoids acutely increase brown adipose tissue activity in humans, revealing species-specific differences in UCP-1 regulation. Cell Metabol. 2016; 24: $130-141$.

Rastogi S, Haldar C. Role of melatonin and HSF-1 \HSP-70 in modulating cold stress-induced immunosuppression in a tropical rodent- Funambulus pennanti. J Therm Biol. 2019; 87: 102456.

Rees D, Nelson G, Kielkowski D, Wasserfall C, da Costa A. Respiratory health and immunological profile of poultry workers. S Afr Med J. 1998; 88:1110-1117.

Robertshaw D. Mechanisms for the control of respiratory evaporative heat loss in panting animals. J Appl Physiol. 2006; 101:664-668.

Romero LM. Physiological stress in ecology: lessons from biomedical research. Trends Ecol. $2004 ; 19: 249-255$

Romero LM. Seasonal changes in plasma glucocorticoid concentrations in free-living 
vertebrates. Gen Comp Endocrinol. 2002; 128:1-24

Rudas P, Pethes G. Acute changes of the conversion of thyroxine to triiodothyronine in hypophysectomized and thyroidectomized chickens exposed to mild cold $\left(10^{\circ} \mathrm{C}\right)$. Gen. Comp. Endocrinol. 1986; 63:408-413.

Rykakina, E. G., S. N. Shanin, I. A. Kozinets, E. E. Fomicheva, and Korneva, E. A. 1996. Cellular mechanisms of cold stress-related immunosuppression and the action of interleukin 1. International journal of tissue reactions. 19: 135-140.

Sahin N, Onderci M, Sahin K, Smith M. Melatonin supplementation can ameliorate the detrimental effects of heat stress on performance and carcass traits of Japanese quail. Biol Trace Elem. Res. 2003; 96:169-177.

Sakomura NK, De Paula Reis M, Ferreira NT, Gous RM. Modeling egg production as a means fo optimizing dietary nutrient contents for laying hens. Anim Front. 2019; 9: 45-51.

Sanderson WT, Weber A, Echt A. Epidemic eye and upper respiratory irritation in poultry processing plants. Appl. Occup Environ Hyg. 1995; 10:43-49.

Schweiger M, Schreiber R, Haemmerle G, Lass A, Fledelius C, Jacobsen P, Tornqvist H, Zechner R, Zimmermann R. Adipose triglyceride lipase and hormone-sensitive lipase are the major enzymes in adipose tissue triacylglycerol catabolism. J Biol Chem. 2006; 281:4023640241.

Sesti-Costa, R., M. D. C. Ignacchiti, S. Chedraoui-Silva, L. F. Marchi, and B. Mantovani. Chronic cold stress in mice induces a regulatory phenotype in macrophages: correlation with increased 11ß-hydroxysteroid dehydrogenase expression. Brain Behavior Immun. 2012; 26: $50-60$

Silberman DM, Wald M, Genaro AM. Effects of chronic mild stress on lymphocyte proliferative 
response. Participation of serum thyroid hormones and corticosterone. Int Immunopharmacol. $2002 ; 2: 487-497$.

Sinclair BJ, Ferguson LV, Salehipout-shirazi G, MacMillan HA. Cross-tolerance and cross-talk in the cold: relating low temperature to desiccation and immune stress in insects. Integr Comp Biol. 2013; 53: 545-556.

Smith SM, Vale WW. The role of the hypothalamic-pituitary-adrenal axis in neuroendocrine responses to stress. Dialogues Clin Neurosci. 2006; 8:383-395.

Sonna, L. A., J. Fujita, S. L. Gaffin, and C. M. Lilly. Invited review: Effects of heat and cold stress on mammalian gene expression. J Appl Physiol. 2002; 92: 1725-1742.

Spinu M, Degan AA. Effect of cold stress on performance and immune responses of Bedouin and White Leghorn hens. Bri Poult Sci. 1993; 34:177-185.

Steel RGD, Torrie JH, Dickey DJ. 1997. Principles and procedures of statistics: A biometrical approach. 3rd ed. McGraw Hill Book Co., New York, NY.

van Iaer E, Moons CPH, Sonck B, Tuyttens FAM. Importance of outdoor shelter for cattle in temperate climates. Livest Sci. 2014; 159: 87-101.

Van Kampen M, Mitchell BM, Siegel HS. Thermoneutral zone of chickens as determined by measuring heat production, respiration rate, and electromyographic and electroencephalographic activity in light and dark environments and changing ambient temperatures. J Agric Sci. 1979; 92:219-226.

Vandenborne K, de Groef B, Geelissen SME, Kuhn ER, Darras VM, van der Geyten S. Corticosterone-induced negative feedback mechanisms within the hypothalamo-pituitaryadrenal axis of the chicken. J Endocrinol. 2005; 185:383-391.

Vandenplas Y, Carnielli VP, Ksiazyk J, Luna MS, Migacheva N, Mosselmans JM, Picaud JC, 
Possner M, Singhal A, Wabitsch M. Factors affecting early-life intestinal microbiota development. Nutrition. 2020; 78:110812.

Winer BJ, Brown DR, Michels KM. 1991. Statistical principles in experimental design. 3rd ed. McGraw-Hill, Inc. New York. NY.

Wrutniak-Cabello C, Casas F, Cabello G. Thyroid hormone action in mitochondria. J Mol Endocrinol. 2001; 26:67-77.

Xin H, Gates RS, Green AR, Mitloehner FM, Moore P, Wathes CM. Environmental impacts and sustainability of egg production systems. Poult Sci. 2011; 90:263-277.

Yan FF, Wang WC, Cheng HW. Bacillus subtilis-based probiotic promotes bone growth by inhibition of inflammation in broilers subjected to cyclic heating episodes. Poult Sci. 2020; 99: 5252-5260.

Zhang Z, Boelen A, Kalsbeek A, Fliers E. TRH neurons and thyroid hormone coordinate the hypothalamic response to cold. Eur Thyroid J. 2018; 7: 279-288.

Zhao Y, Xin H, Shepherd T, Hayes M, Stinn J, Li H. Thermal environment, ammonia concentrations, and ammonia emissions of aviary houses with white laying hens. Transactions of the ASABE. 2013; 56:1145-1156.

Zhao Z, Yang WZ, Gao C, Fu X, Zhang W, Zhou Q, Chen W, Ni X, Lin J, Yang J, Xu XH, Shen W. A hypothalamic circuit that controls body temperature. PNAS. 2017; 114: 2042-2047.

Zhao, F. Q., Z. W. Zhang, J. P. Qu, H. D. Yao, M. Li, S. Li, and S. W. Xu. Cold stress induces antioxidants and Hsps in chicken immune organs. Cell Stress Chaperones. 2014; 19: 635-648.

Zheng WH, Lin L, Liu JS, Xu XJ, Li M. Geographic variation in basal thermogenesis in little buntings: relationship to cellular thermogenesis and thyroid hormone concentrations. Comp Biochem Phys A. 2013; 164:483-490. 
Table 1.

\begin{tabular}{|c|c|c|c|c|c|}
\hline Treatment & $\begin{array}{c}\text { Rectal } \\
\text { Temperature } \\
\left({ }^{\circ} \mathrm{C}\right)^{1}\end{array}$ & $\begin{array}{c}\text { Foot Surface } \\
\text { Temperature }^{2} \\
\left({ }^{\circ} \mathrm{C}\right)\end{array}$ & $\begin{array}{c}\text { Feed } \\
\text { Intake }(\mathrm{g})\end{array}$ & $\begin{array}{l}\text { Body Weight } \\
\operatorname{Loss}^{3}(\%)^{2}\end{array}$ & $\begin{array}{l}\text { Hen-Day Egg } \\
\text { production }(\%)^{3}\end{array}$ \\
\hline $\mathrm{AP}$ & $40.66^{\mathrm{a}}$ & $18.39^{\mathrm{b}}$ & 133.9 & 10.02 & 87.8 \\
\hline NP & $40.29^{b}$ & $13.01^{\mathrm{c}}$ & 141.7 & 8.02 & 84.9 \\
\hline WP & $40.64^{a}$ & $29.14^{\mathrm{a}}$ & 121.3 & 5.25 & 93.6 \\
\hline$n^{4}$ & 12 & 24 & 12 & 12 & 12 \\
\hline \multicolumn{6}{|l|}{$P$-Value } \\
\hline SEM & 0.005 & 1.23 & 6.05 & 1.48 & 4.0 \\
\hline$P$ treatment & $<0.0001$ & $<0.0001$ & 0.06 & 0.09 & 0.33 \\
\hline$P_{\text {age }}$ & $<0.0001$ & 0.0003 & 0.0002 & 0.61 & 0.04 \\
\hline 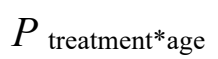 & 0.98 & 0.77 & 0.94 & 0.99 & 0.84 \\
\hline
\end{tabular}

${ }^{\mathrm{a}, \mathrm{b}}$ Least squares means within a column for the 3 treatments lacking a common superscript $\operatorname{differ}(P<0.05)$.

${ }^{1}$ Values within a column represent the least squares means averaged over 4 measured time points (day 1, 8, 15, and 21 after initiation of cold stress).

${ }^{2}$ Values within a column represent the least squares means averaged over 3 measured time points (Weekly after initiation of cold stress).

${ }^{3}$ Body weight change was calculated as measured body weight/original body weight* $100 \%$.

${ }^{4}$ Average number of observations per least squares mean. 
Table 2.

\begin{tabular}{lcccc}
\hline \hline Treatment & $\begin{array}{c}\text { Egg Weight } \\
(\mathrm{g})\end{array}$ & $\begin{array}{c}\text { Breaking Force }^{1} \\
(\mathrm{~N})\end{array}$ & $\begin{array}{c}\text { Shell Thickness }^{1} \\
(\mathrm{~mm})\end{array}$ & $\begin{array}{c}\text { Shell Percentage }^{1} \\
(\%)\end{array}$ \\
\hline AP & 55.82 & 42.07 & 0.35 & 9.35 \\
NP & 56.89 & 44.80 & 0.35 & 9.27 \\
WP & 55.51 & 44.14 & 0.35 & 9.49 \\
$\mathrm{n}^{2}$ & 96 & 96 & 96 & 96 \\
$P$-Value & & & & 0.11 \\
SEM & 0.50 & 1.19 & 0.004 & 0.37 \\
$P_{\text {treatment }}$ & 0.13 & 0.21 & 0.75 & 0.75 \\
$P_{\text {age }}$ & 0.47 & 0.52 & 0.89 & 0.14 \\
$P_{\text {treatment }}$ & 0.74 & 0.13 & 0.03 & \\
\hline
\end{tabular}

${ }^{1}$ Values within a column represent the least squares means of 4 eggs from each of the 3 treatments averaged over 2 ages.

${ }^{2}$ Values within a column represent the least squares means averaged over 3 week of egg production ( 32 to 34 week).

${ }^{3}$ Average number of observations per least squares mean. 
Table 3.

\begin{tabular}{|c|c|c|c|c|c|c|}
\hline Treatment & $\operatorname{CORT}(\mathrm{ng} / \mathrm{ml})^{1,2}$ & $\mathrm{~T} 3(\mathrm{ng} / \mathrm{dl})^{1,2}$ & $\mathrm{~T} 4(\mathrm{ug} / \mathrm{dl})^{1,2}$ & $\mathrm{~T} 3 / \mathrm{T} 4$ & IL-6 $(\mathrm{pg} / \mathrm{ml})^{1,2}$ & IL-10 $(\mathrm{pg} / \mathrm{ml})^{1,2}$ \\
\hline AP & 6.68 & 160.36 & $12.76^{\mathrm{b}}$ & 0.013 & 34.43 & 90.16 \\
\hline NP & 6.13 & 164.82 & $13.67^{\mathrm{a}}$ & 0.012 & 36.46 & 94.27 \\
\hline WP & 5.74 & 173.25 & $14.23^{\mathrm{a}}$ & 0.012 & 42.15 & 88.35 \\
\hline$n^{3}$ & 12 & 12 & 12 & 12 & 12 & 12 \\
\hline SEM & 0.72 & 7.21 & 0.79 & 0.0004 & 4.13 & 8.56 \\
\hline \multicolumn{7}{|l|}{$P$-Value } \\
\hline$P$ treatment & 0.65 & 0.46 & 0.002 & 0.69 & 0.43 & 0.88 \\
\hline$P_{\text {age }}$ & 0.12 & 0.81 & 0.03 & 0.21 & 0.08 & 0.001 \\
\hline$P_{\text {treatment*age }}$ & 0.07 & 0.07 & 0.23 & 0.05 & 0.04 & 0.26 \\
\hline
\end{tabular}

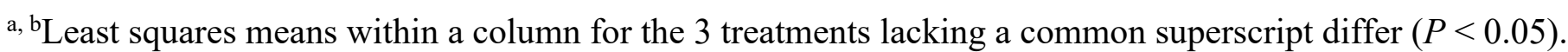

${ }^{1}$ CORT: Corticosterone; T3: 3,3',5-triiodothyronine; T4: Thyroxine; IL-6: interleukin 6; IL-10: interleukin 10.

${ }^{2}$ Values within a column represent the least squares means averaged over 2 measurements (day 1 and day 21 of cold stress).

${ }^{3}$ Average number of observations per least squares mean. 


\section{Figure Legend:}

Figure 1. Cage bank design for the 3 treatments: warm perch (WP) cages (1a), air perch (AP) cages (1b), and control cages with no perches (NP) (1c). Two perches were installed parallel in each row of a cage bank. For the WP cages, an electric water heater was used to supply warm water $\left(30^{\circ} \mathrm{C}\right)$ to each row. The figure illustrates temperature recording locations $(\diamond)$ for measuring the water/air temperature at the warm perch and air perch (non-warmed perch). Air temperature and relative humidity ( $\square$ ) within each treatment and deck level (top, middle, and bottom) of the cages and in the room will be continuously recorded.

Figure 2. An example of the treatments' temperatures recorded for $24 \mathrm{~h}$ during cold exposure (0000 to $2400 \mathrm{~h}$, from top to bottom, line 1: warm perch (WP) supply water temperature, line 2: warm perch (WP) return water temperature, line 3: warm perch (WP) cage temperature, line 4: air perch (AP) cage temperature, line 5: room temperature (RT) (a), and examples of the feet thermographic images of a hen perching on a warmed perch (b) and on an air perch (c).

Figure 3. The shell thickness of eggs collected from DeKalb hens submitted to 1 of 3 treatments $(\boldsymbol{\Delta}=$ air perch or AP,

$\mathrm{NP}, \boldsymbol{\square}=$ warm perch or WP) between the $1^{\text {st }}$ and $3^{\text {rd }}$ week of cold exposure. ${ }^{\text {a,b }}$ Within an age, least squares means \pm SEM with no common letter are significantly different (treatment $\times$ age interaction, $P=0.03$ ).

Figure 4: The T3/T4 ratio (a) and plasma interleukin (IL)-6 (b) of DeKalb hens submitted to 1 of 3 treatments $(\boldsymbol{\Delta}=$ air perch or AP,

= control or NP, warm perch or WP, $\mathbf{\square}=$ warm perch or WP) between the 1 day and $3^{\text {rd }}$ week of cold exposure. ${ }^{\text {a,b }}$ Within an age, least squares means $\pm \mathrm{SEM}$ with no common letter are significantly different (treatment $\times$ age interaction, $P=0.05$ ) 
Figure 1:

$1 \mathrm{a}$

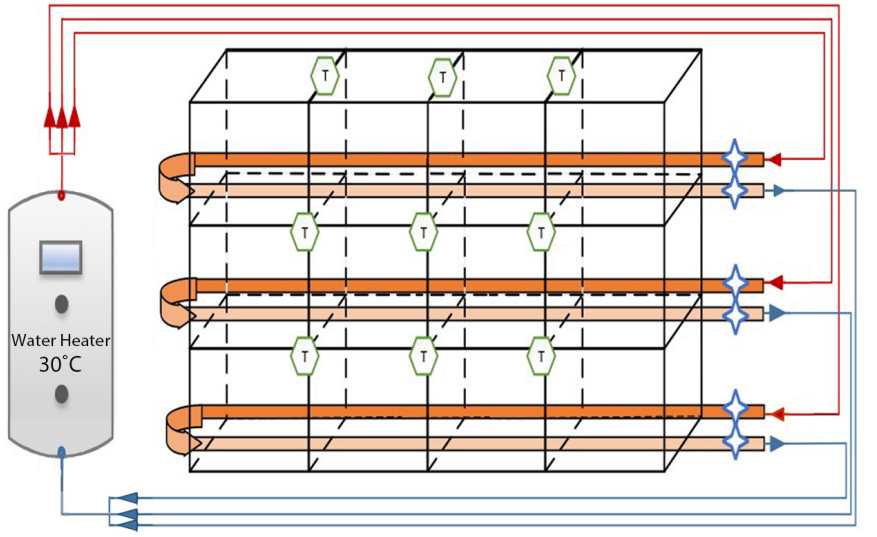

$1 b$
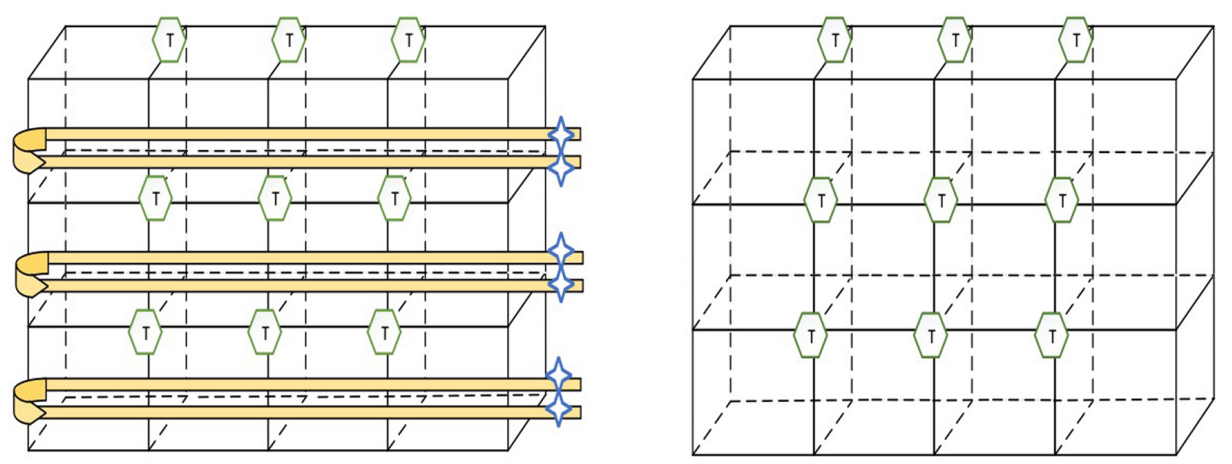
Figure 2

(a)

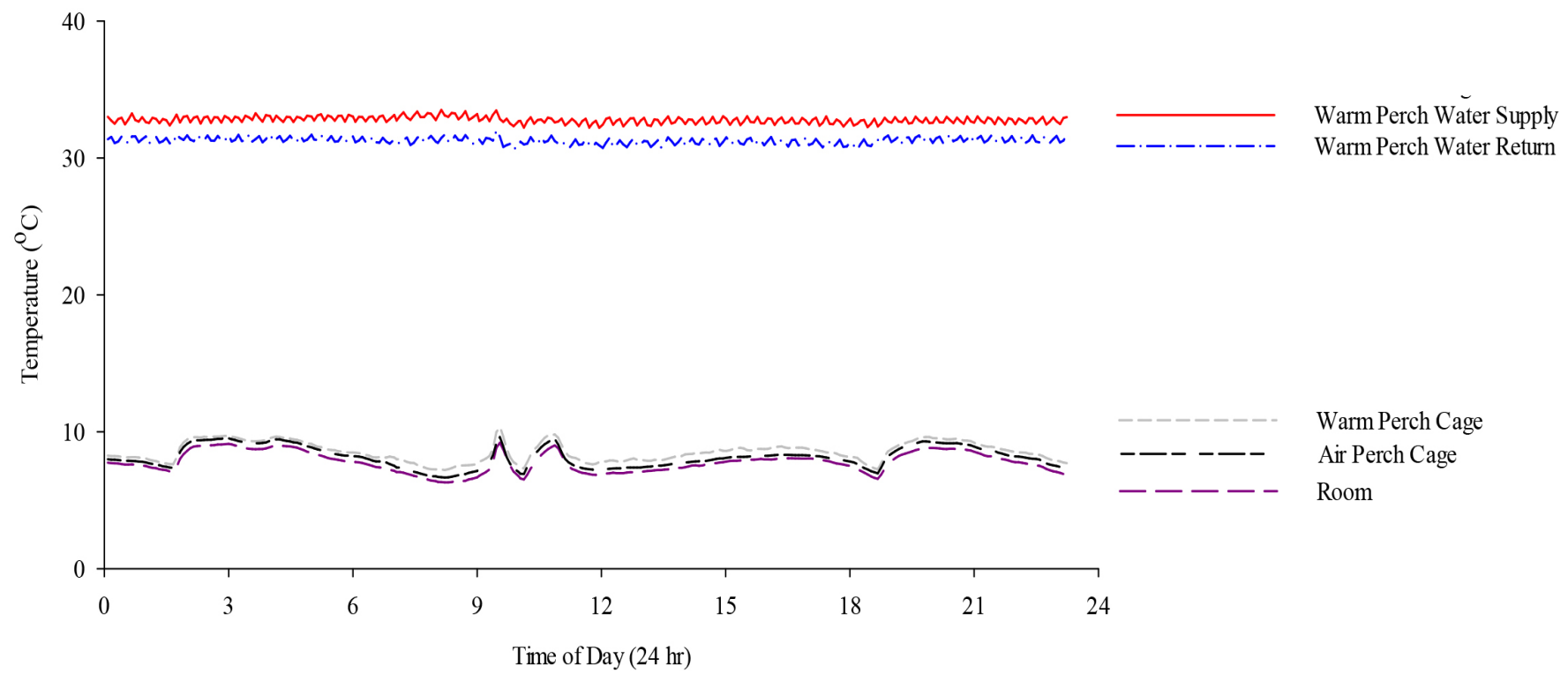

(b)

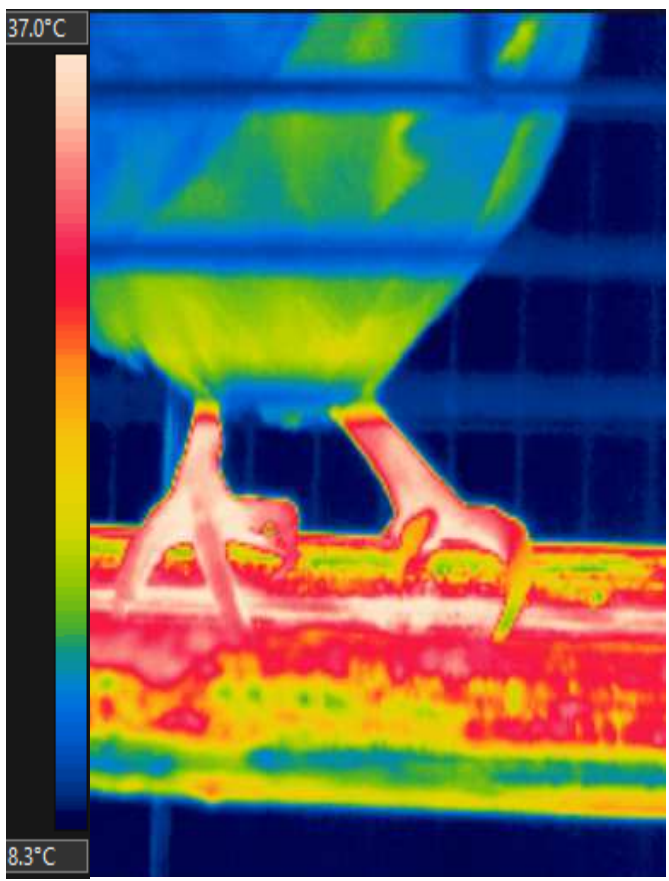

(c

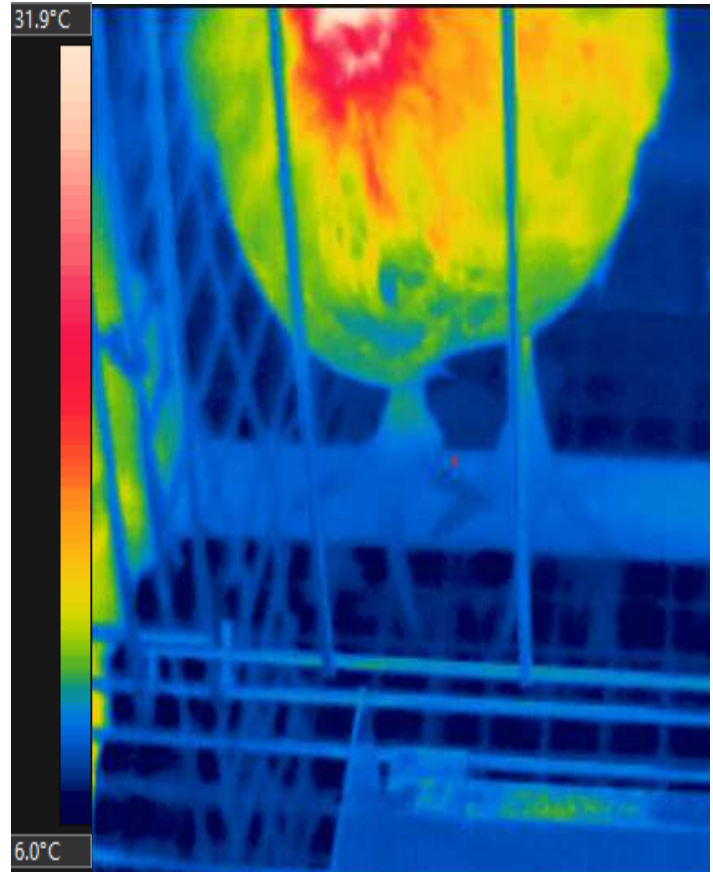


Figure 3:

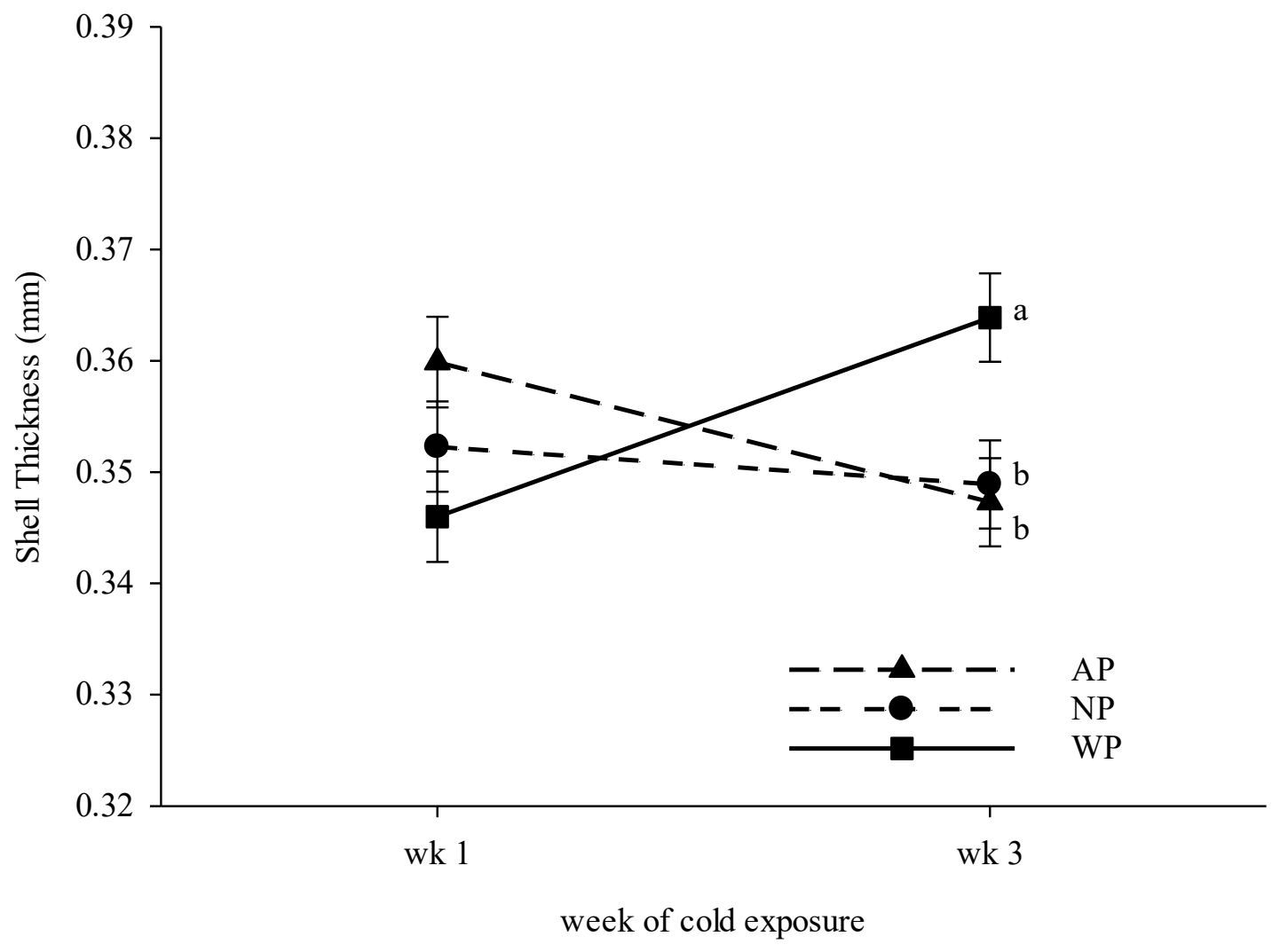


Figure 4:

$4 a$

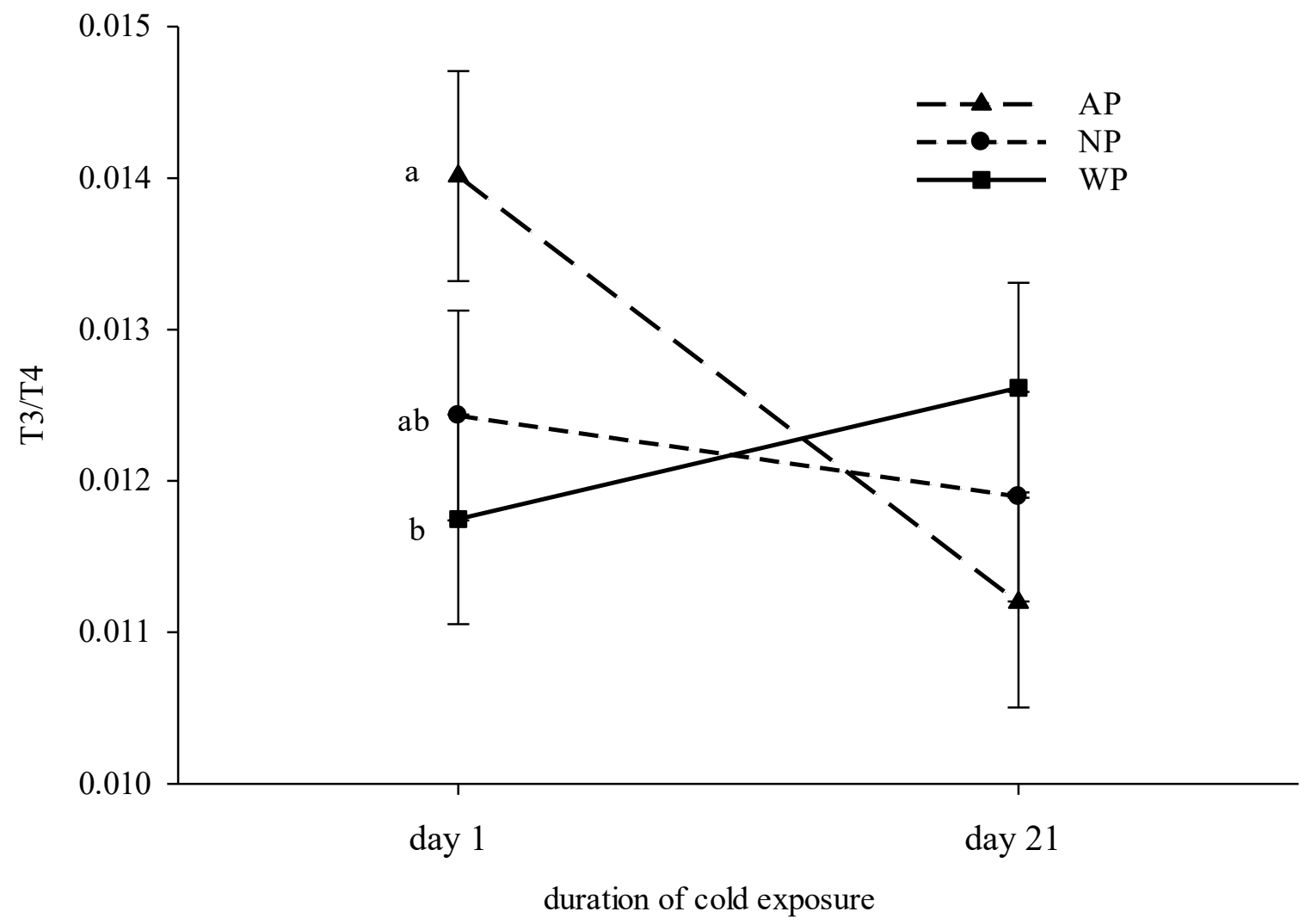




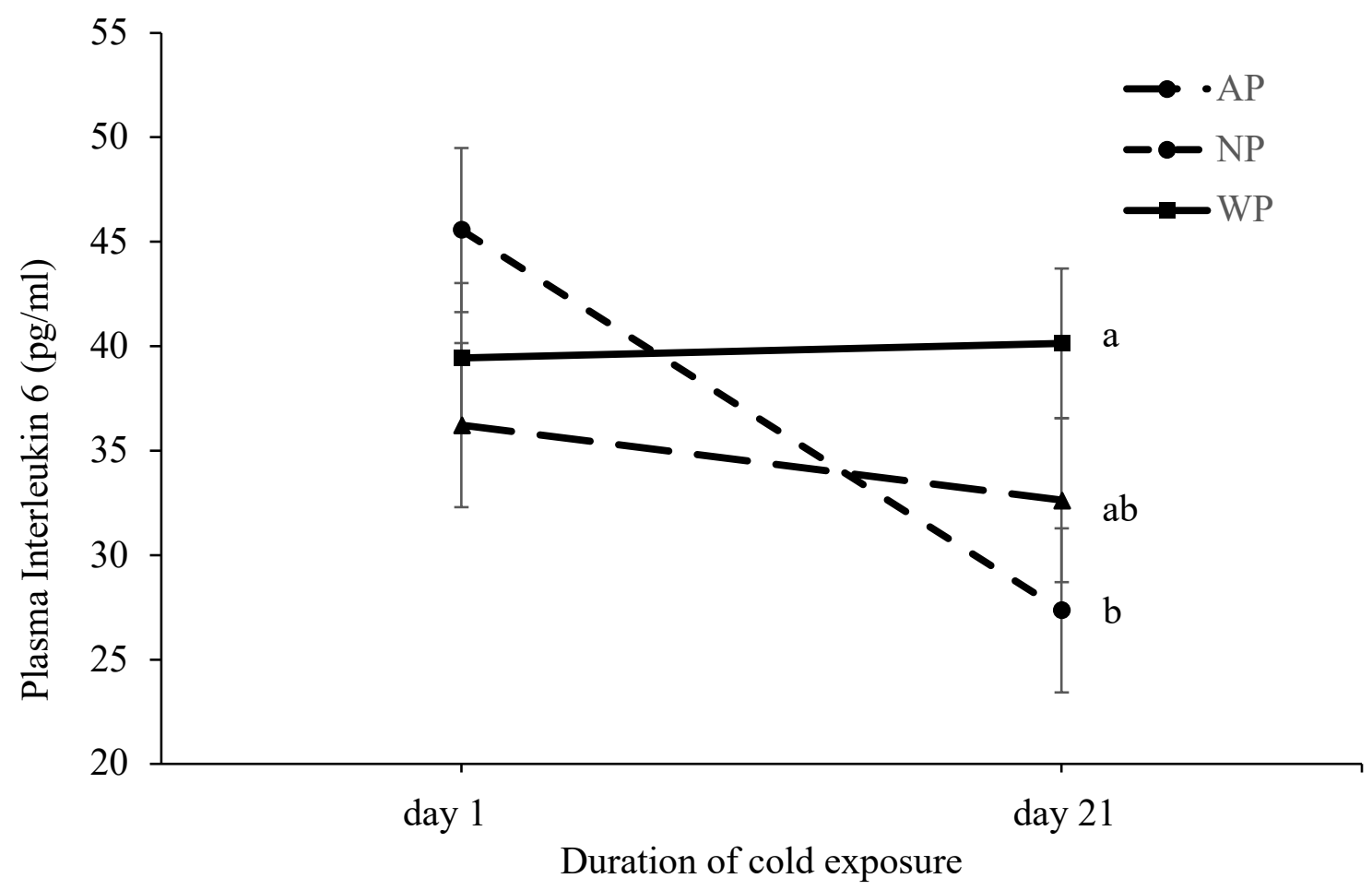




\section{Figures}

1a

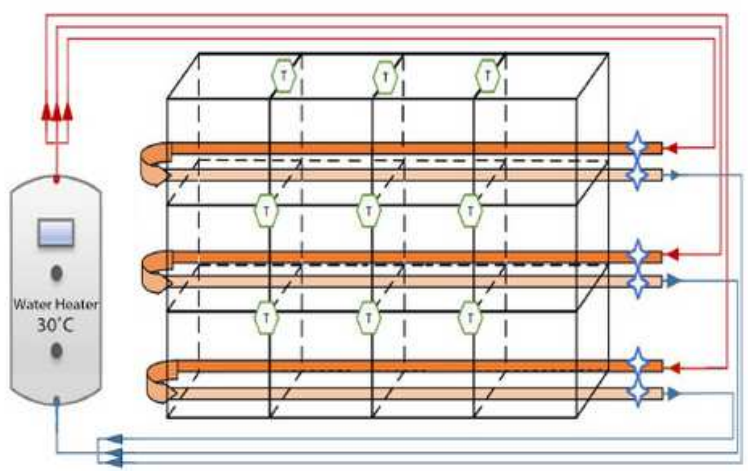

$1 b$

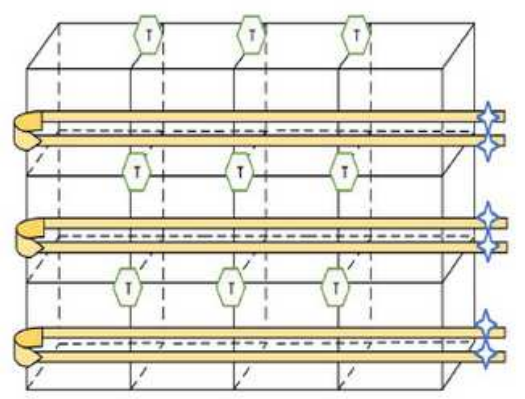

$1 \mathrm{c}$

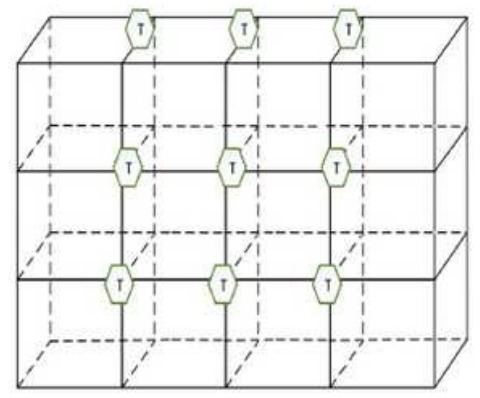

\section{Figure 1}

See the Manuscript Files section for the complete figure caption. 
(a)

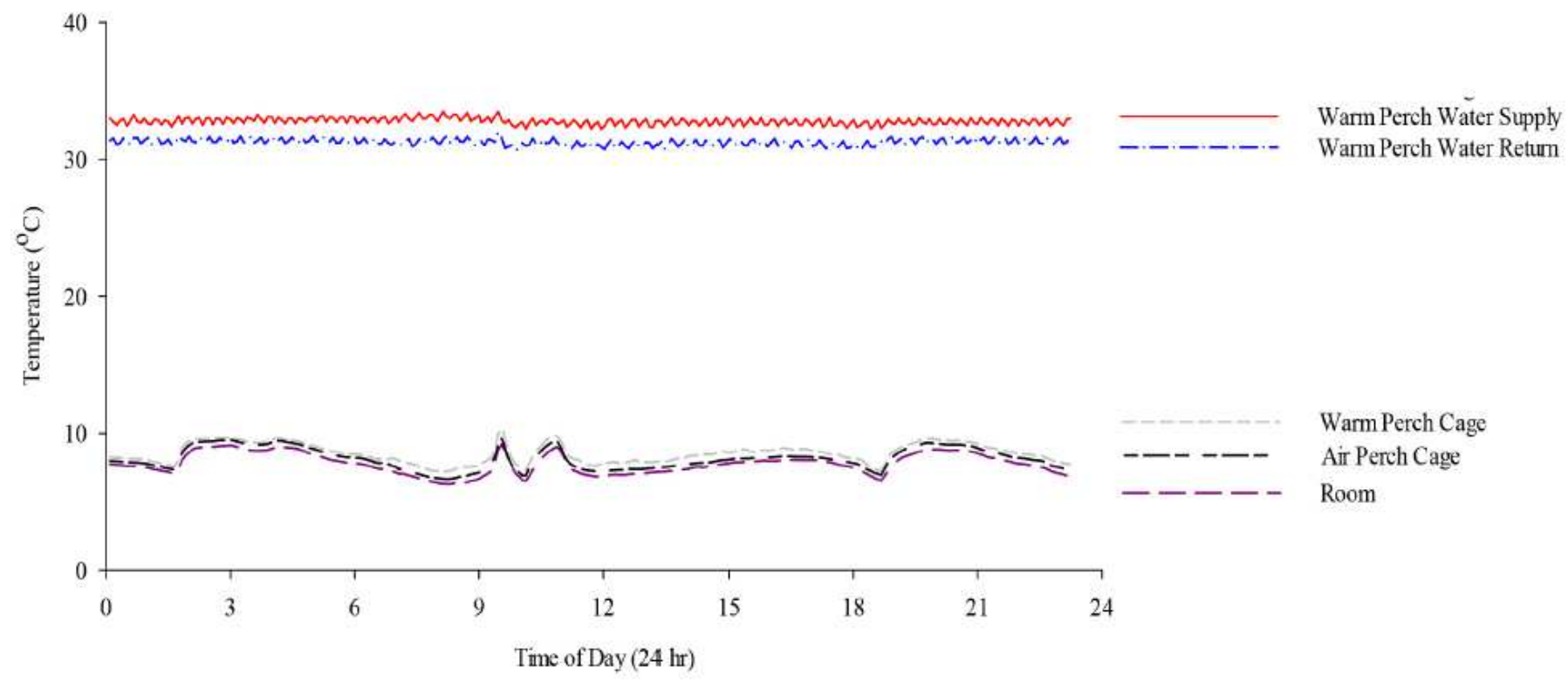

(b)

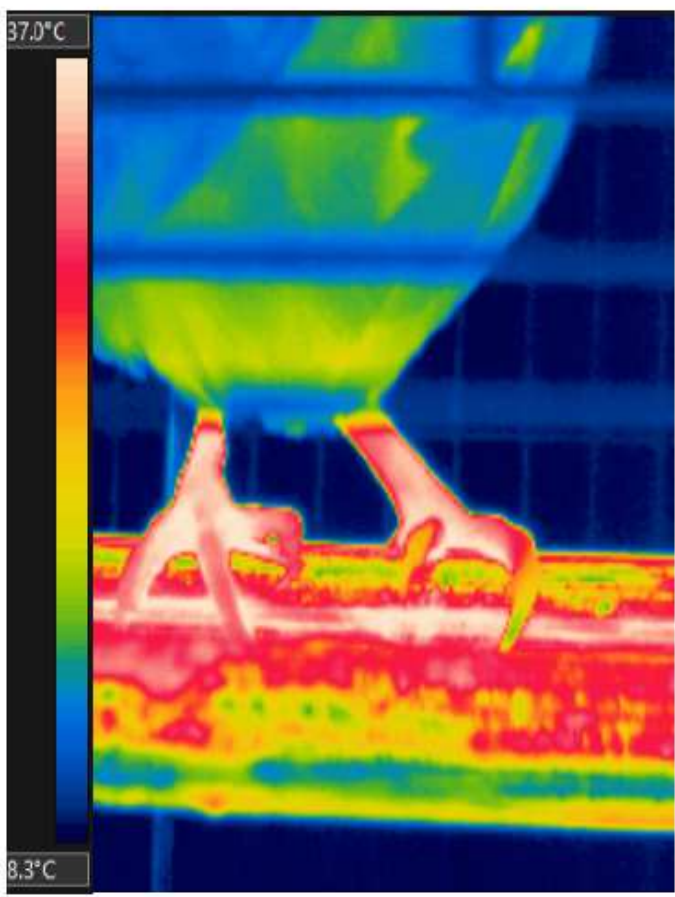

(c

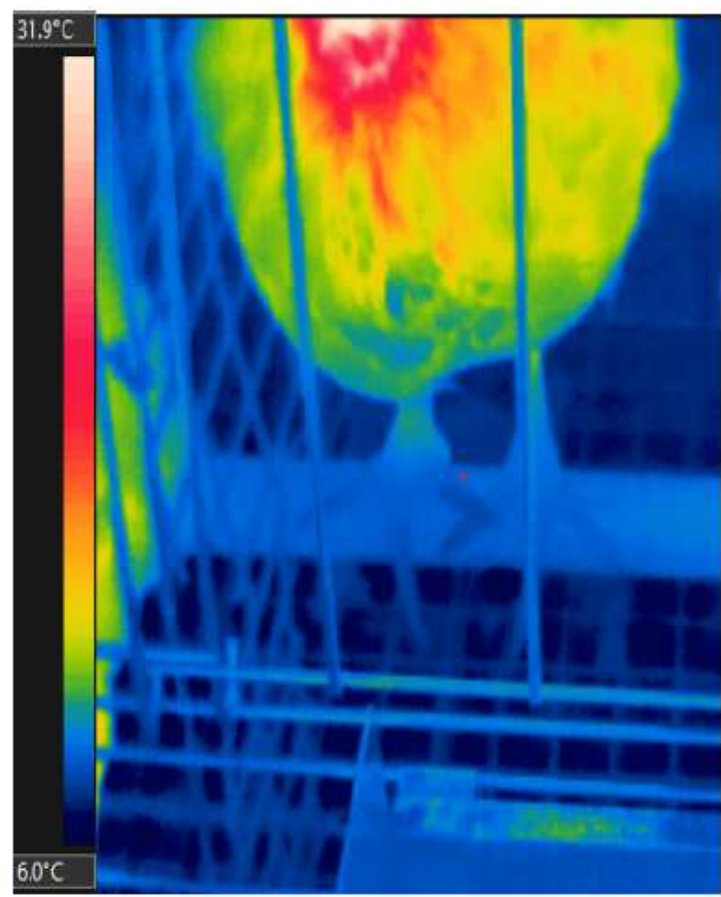

Figure 2

See the Manuscript Files section for the complete figure caption. 


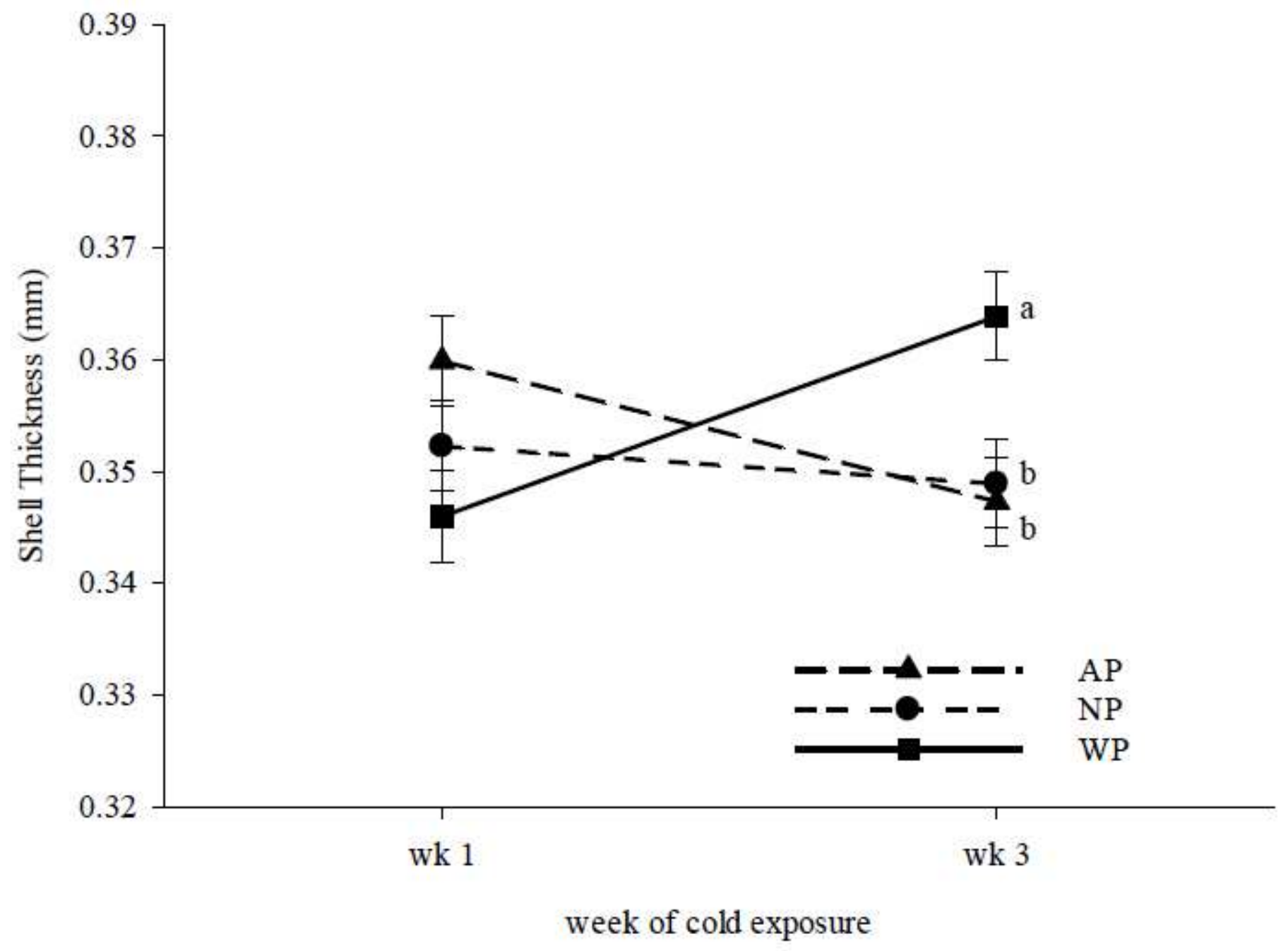

Figure 3

See the Manuscript Files section for the complete figure caption. 

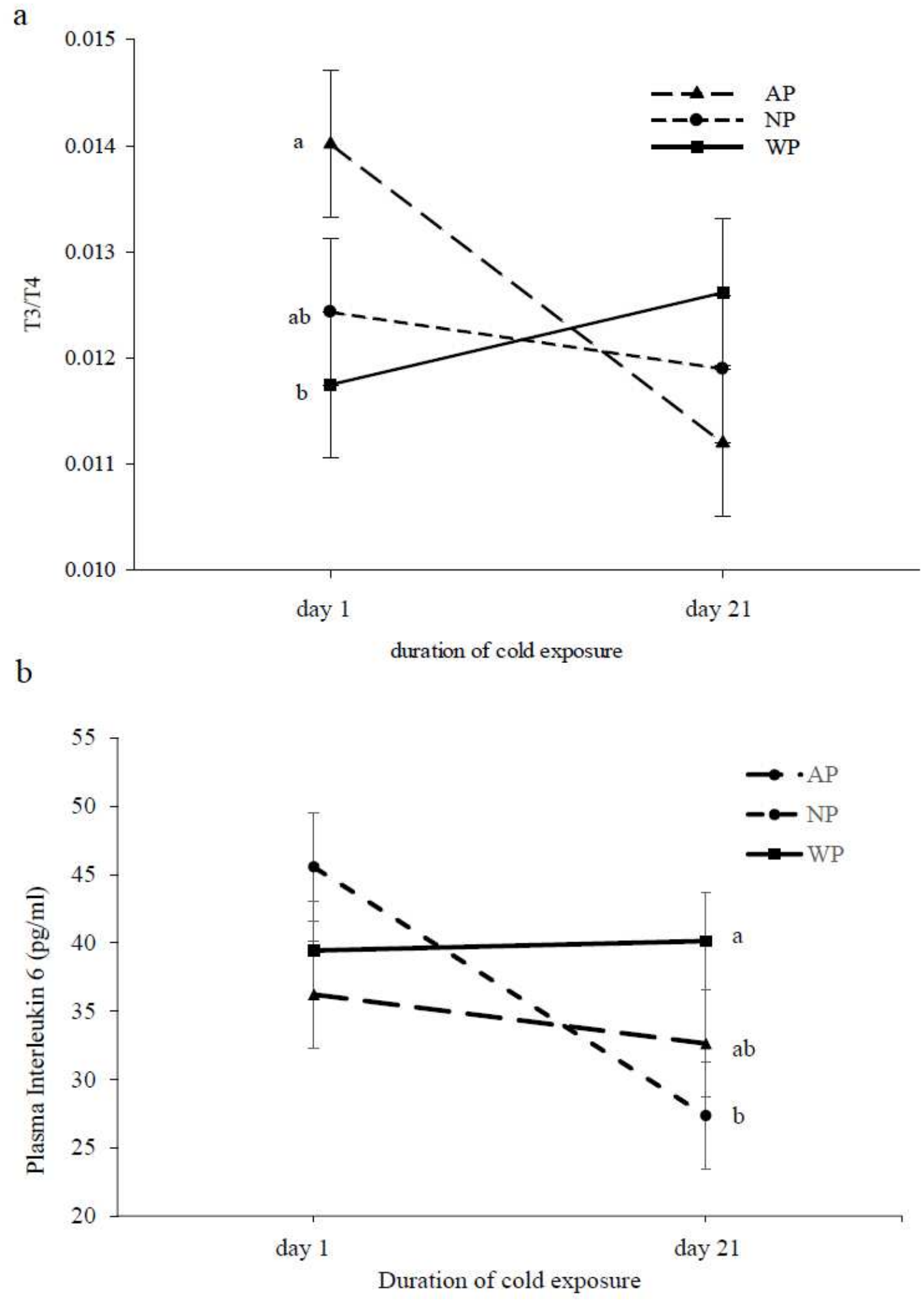

Figure 4

See the Manuscript Files section for the complete figure caption. 